\title{
The Times of the Faculty: Variations in the Length of the Workweek of Faculty at Flemish Universities
}

\author{
Ronan Van Rossem ${ }^{1}$ \\ ${ }^{1}$ Ghent University, Ghent, Belgium \\ Correspondence: Ronan Van Rossem, Department of Sociology, Universiteit Gent, Korte Meer 5, 9000 Gent, \\ Belgium. Tel: 32-9264-6796. E-mail: ronan.vanrossem@ugent.be
}

Received: July 28, 2018

Accepted: August 14, $2018 \quad$ Online Published: November 24, 2018

doi:10.5539/hes.v9n1p9

URL: https://doi.org/10.5539/hes.v9n1p9

\begin{abstract}
Over the past decade discontent in Flemish universities with the increased work load of faculty members has risen. This study is the first to examine how many hours a week senior researcher (postdocs and faculty) in Flemish universities actually work.

The data used stems from the 2010 Survey of Senior Researcher conducted among senior researchers at the five Flemish universities. 1195 respondents provided information on their working hours.

Senior researchers worked on the average 50.4 hours a week, with $12 \%$ reporting to work more than 60 hours a week. The number of hours worked varied significantly with rank, where respondents in more senior ranks reported to work more hours. Once one controls for rank any gender differences in number of hours work disappear.

We did observe a significant trade-off between the time spent on various activities. Postdocs spent more time on research than the other ranks, and senior professors spent more time on service and administration. Respondents from the humanities, and to a lesser degree from the social sciences, spent more time on education than respondents from other disciplines.

This study confirms that senior researchers at Flemish universities work long hours, and that the number of hours spent on various activities is largely a reaction to demands from their institutional environment.
\end{abstract}

Keywords: higher education, Flanders, working time, faculty

\section{Introduction}

Faculty members closely fit the stereotype of a professional, Traditionally they enjoyed great liberties to organize their own work, guided by professional standards rather than organizational ones. However, the university environment is changing, in Flanders as well as elsewhere: it is becoming more bureaucratized and centralized, productivity and accountability have gained importance, the number of students is rising much more rapidly than the number of faculty members, and the social value of a university education and social status of faculty declining. Illustrative of this evolution is the 2010 incident in Flanders when the president of the Catholic University of Leuven mentioned that Flemish universities faced a serious shortage of faculty members given the increased workload (Bruynhooghe, 2010), and the minister of education quite laconically suggested that they simply should work harder (bbd [Dobbelaere], 2010) reinforcing the image that university faculty have quite cosy jobs. In fact, little information exists on how hard and long faculty members at Flemish universities actually work. This paper presents information from a large survey among senior academic staff on the number of hours faculty members of the Flemish universities report to work and what factors affect the time use of faculty.

The international literature shows that faculty members tend to work long hours. The job is demanding both in terms of the time and of the energy and commitment it requires (Jacobs \& Winslow, 2004). The number of hours worked varies substantially across countries (Bentley \& Kyvik, 2012; Enders \& Teichler, 1997) . According to the Bentley and Kyvik study (2012) on 13 countries, the average weekly number of hours worked by full-time faculty when classes are in session over all countries was 48.4 hours a week, but it varied from 52.8 in Hong Kong to 45.2 in Argentina. Enders and Teichler (1997) found that while Dutch professors on the average worked 57 hours a week during teaching weeks, their Swedish colleagues only worked 45 hours. These differences between countries are attributed to "national higher education traditions and patterns of workplace relations" 
(Bentley \& Kyvik, 2012:545), while convergences relate to the international diffusion of norms and institutional arrangements. Worth noticing however is, that despite the variation across countries, in all countries studied the average work week of a faculty member exceeded the normal number of hours that one is expected to work (see also: Anderson \& Slade, 2016; Kenny \& Fluck, 2017).

Substantial variations in the number of hours worked exist both across and within countries and even within institutions. These observed differences are explained by the context and by the demands posed on the faculty members. Past studies focused mainly on the type of institution (Singell \& Lillydahl, 1996), scientific discipline (Cummings \& Finkelstein 2012), and the phase of the career of the faculty members (Singell \& Lillydahl, 1996) as affecting working hours and the time allocated to various tasks.

The number of hours worked by faculty members is the result of both the demands placed on them by their universities, and of cultural factors that shape expectations and norms. According to neo-institutional theory (March \& Olsen, 2006; Milem, Berger, \& Dey, 2000; Scott, 2008) the functioning of organizations and their members is ruled by regulative, normative and mimetic mechanisms. First, there is the national, or in Belgium, the regional research and education policies, which for publicly funded universities not only set directions and standards for education and research, but also determine the funding criteria. Over the past decades, the Flemish government, in the wake of the Lisbon strategy, has increasingly stressed the importance of research for the development of a knowledge economy. This is reflected in an increased weight of research output such as publications, doctorates and patents in the funding for the universities. The democratization of higher education and the increased inflow of students put more and more constraints on teaching practices. The increased emphasis on public accountability of universities has led to more intense administrative oversight and more formal evaluation procedures for both institutions and staff (Craig, Amernic, \& Tourish, 2014; Kim, 2008; Trakman, 2008). Second, universities are concerned about their own status within the national and international academic communities, comparing themselves to competing universities, and copying strategies from more successful or higher status universities (Knight, 2015; Seeber, Cattaneo, Huisman, \& Paleari, 2016). Both trends predict a convergence in the institutional arrangements and practices of the Flemish universities, including their expectations of and the demands on their faculty members.

These institutional constraints shape the context in which the faculty works. It defines what is expected from them, the evaluation procedures and criteria, as well as their career prospects. It not only determines the number of courses they teach, but also their required research output, project financing to obtain, doctoral students to supervise, administrative tasks to take up, etc., i.e., what they have to spend their time on. However, faculty working hours are not simply a response to organizational demands, they are also an aspect of an internalized faculty role, acquired through socialization during their Ph.D. track or on the job, but also by discipline specific norms transferred through the "invisible college" (Crane, 1969). Academics look to their peers, both at the own institution and in the (inter)national academic community for guidelines on what constitute expected work practices, including output and time spent on various activities. This implies that practices may differ not only by country, but also by institution and discipline.

Studies of the working times of faculty members have focused not only on variations in the total number of hours worked, but also the time invested in various activities with an emphasis on the potential trade-off between education and research. The 'academic ratchet' model (Gardner \& Veliz, 2014; Massy \& Zemsky, 1994; Zemsky, Wegner, \& Massy, 2005) predicted that faculty members would start spending more time on research and less on education related activities. However, Milem et al. (2000) found in their longitudinal study that extra time spent on research did not occur at the expense of education related activities and that over the period they studied faculty members overall increased both the time spent on research and on education. Therefore, it is not always so that there is a trade-off between the times spent on various activities, but that the time spent on different activities can be independent or complimentary as well. In both cases the total number of hours worked increases when more time is spent on one type of activities, be it education, research or administration.

Milem et al. (2000) paid much attention to the type of institution as factor determining how faculty members spend their time. Large research universities expect a different pattern of activities from their faculty than small teaching colleges. In the Flemish context the type of institution is less relevant as all universities are research universities. They all function within the same institutional context and therefore the demands on the faculty vary little over the institutions. Faculty working hours and their distribution of various tasks, therefore, should not vary substantially over the universities.

Flemish universities still heavily depend on public funding, especially for their core tasks, including faculty salaries. Over the past decade research output has become an increasingly important criterion for funding, as 
well as for the evaluation of researchers/faculty. The pressure for higher research output is most urgently felt by junior faculty members who still face tenure or promotion decisions and who therefore have an incentive to spend more hours on research. More senior faculty members should be less susceptible to such demands. The 'academic ratchet' in which research gets priority over education, is de facto promoted by both the Flemish government and the universities.

Compared to only a few decades ago, professors today face increasing workloads and monitoring. They are expected not only to be top researchers, but also excellent teachers and competent administrators who also reach out to non-academic circles. While the number of faculty members has remained relatively stable over the past thirty years rising from 2506.6 FTE in 1982 to 2601.0 in 2010, i.e., an increase with only $3.8 \%$ over this period (VLIR, 2010), the number of students has increased substantially faster, from 48,543 in 1981-1982 to 82,350 in 2010-2011, i.e., an increase with 70\% over this period (Ministerie van Onderwijs en Vorming, 2011). The scientific staff, mainly doctoral students, grew over the period 1982-2010 with 323\%, from 2624.2 FTE to 11,119.8 FTE (VLIR, 2012). In recent years the number of faculty members at Flemish universities has increased substantially, to 3384.9 FTE in 2017, an increase of 30\% compared to 2010 (VLIR, 2017) . But this is misleading as much of the increase can be attributed to the transfer of academic programs from the non-university institutions of higher education to the universities, including their teaching staff. The number of students increased by the academic year 2017-2018 to 118,601 (Ministerie van Onderwijs en Vorming, 2017), i.e., an increase of $44 \%$ since 2010-2011. The increase of the scientific staff size was less pronounced with only an increase of $18 \%$ between 2010 and 2017 to 13,144.6 FTE (VLIR, 2017). All evidence thus points to a substantial increase of the faculty's workload over the past decades. Similar trends have also been observed in other countries (Bentley \& Kyvik, 2012; Welch, 2005). Workload is only one factor affecting how many hours one works. Other factors include legal regulations concerning working hours, career considerations and evaluation criteria, competing demands from various sources, and informal norms among the faculty regarding acceptable working times.

Although in Belgium the legal working week is put at 38 hours, faculty members do not hold to regular working hours. Like many professionals they do not work according to fixed work schedules, but rather according to the demands of the job and their intrinsic motivation (Blackburn \& Lawrence, 1995; Bozeman \& Gaughan, 2011). They enjoy substantial autonomy, both with regard to the content of their work and to its organization (Gappa, 2010; Teichler, 2017; Teixeira, 2017). To the extent that there is control it is output oriented, i.e., on the number and quality of publications acquired funding, teaching evaluations, etc., rather than on the number of hours they put in. The output demands, which have become increasingly important over the past few decades, not only for the evaluation of the faculty members, but also for their standing in the academic community, to a considerable degree determine the time faculty members spend on their job.

Except for teaching and some administrative tasks there a few formal demands on the time of faculty members. Informal norms emanating from the "invisible college" (Crane, 1969; Hackett, Parker, Vermeulen, \& Penders, 2017) of colleagues and the scientific community define what is expected from faculty members at a given rank and a certain type of institution, including the time they spend on various activities. The total time worked and the time spent on various activities results from balancing the many demands placed on the faculty members. Choices need to be made as to how much time is devoted to each activity.

The scientific discipline of the faculty member affects both the workload and the work norms. Student-faculty ratios vary substantially over disciplines, being higher in the humanities and social sciences than in the natural and applied sciences. For instance, in 2017 the student-faculty ratio, counting only bachelor students, was 16.7 in history, and 19.7 in the political and social sciences, but only 5.9 in chemistry (own calculations based on Ministerie van Onderwijs en Vorming, 2017; and VLIR, 2017). The latter often also have to teach fewer courses. This implies that faculty members in the humanities and social sciences on the average will spend more time on education related activities, and this potentially at the expense of the time spent on research activities or leading to longer work weeks.

The demands on faculty members also vary with their rank. The underlying idea is that faculty members are in competition with each other and tend to work long hours to position themselves for future career moves, i.e., to get tenure or promotion. In many countries junior faculty members need to bring together a competitive portfolio to obtain tenure which requires them to work many hours not only on research, but also preparing new courses. Once tenure is achieved this pressure lessens although competitive pressures for promotion and positive evaluations remain. In the Flemish context such competitive pressures tend to be minimal. Traditionally all new faculty members at any rank were tenured from the start. Only since 2009 lecturers are appointed under a tenure-track system which qualifies them for tenure after five years, but it is still unclear whether this will 
change much in practice and have any effect on the careers of faculty members (Vlaamse Raad voor Wetenschapsbeleid, 2008a, 2008b). At higher ranks there is little competition for promotion, as most eventually become full professors. Furthermore, the salary of faculty members is independent of their performance and follows fixed salary scales.

The only level at which there is fierce competition for scarce positions is the entry level rank of Flemish academia, i.e., among the postdocs. Several years of postdoc experience is a precondition to be hired into a tenure-track assistant professor/lecturer position. Career prospects are slim for most postdoctoral researchers as only few of them can join the faculty ranks. This implies that there is considerable pressure on these post-doctoral researchers to publish. Usually they only have limited teaching or administrative responsibilities and therefore can spend most of their time on research.

Although formally little changes in the job description when rising through the ranks, some positions, such as dean, department chair, etc., are reserved for the more senior ranks. It is expected that with seniority one takes more administrative responsibilities and thus spends more time on administrative tasks. This may lead to a reduction in the time spent on other activities such as teaching and research. As senior faculty may also teach smaller and more specialized courses, they may spend less time on education. For instance, Link, Swann, and Bozeman (2008) found that the number of hours spent on research decreased with both seniority and rank, while time spent on education activities declined with seniority only for full professors. The amount of time spent on service tasks did increase with seniority.

Postdocs and faculty members not only face demands from their professional environment, but from their personal and family life as well. Partners and children also put claims on the time of senior researchers, which compete with those of their professional environments. The marital status and the family composition of the researcher therefore have an effect on his or her time allocation, with singles without children having most freedom to work longer hours. Given the gendered nature of the division of labor at home, one can expect that women will feel more pressures on their time from the family environment than men (Dorenkamp \& Süß, 2017; Jacobs \& Winslow, 2004). Women still have more domestic and family responsibilities than men, even among better educated households and despite decades of campaigns for a more equal division of labor in the family (Benschop \& Brouns, 2003; Kurtz - Costes, Andrews Helmke, \& Ülkü - Steiner, 2006; Van den Brink, 2010). Women with children therefore will face more constraints on their time use due to domestic and family obligations, and will therefore be less able to invest in their careers than their male colleagues.

However, academia has a reputation of being a male-dominated bastion, often quite hostile to women (Reay, 2004). Women, therefore, often feel they have to prove themselves more than men in order to get equally acknowledged for their achievements, and therefore, will be more likely to work longer hours to secure their academic careers (Van den Brink, 2010). Within the university there also may be a gender division of labor, with men spending more time on research and women more on teaching and service (Cummings \& Finkelstein 2012; Link et al., 2008; Winslow, 2010). However, such results may partly mask the different gender composition over the disciplines, with women underrepresented in the natural and applied sciences where the teaching load is lighter.

\section{Methods}

\subsection{Sample}

This study uses the June 2010 Survey of Senior Researchers (SSR) (for more information, see: Leyman, Vandevelde, Van Rossem, \& Groenvynck, 2011). 4,745 senior researchers (i.e., post-doctoral researchers) employed at the 5 Flemish universities were invited to participate in this web-survey. In the introductory mail the purpose of the survey was explained, as well as its voluntary nature. As these mails were sent by the participating universities, the surveys were anonymous to the researchers. 1,903 (or 40.1\%) senior researchers did participate in the web-survey. Of these 1,195 (or 62.8\%) answered the questions on working hours. Only the latter were retained for the analyses, resulting in an effective response rate of $25.2 \%$. The effective sample deviate slightly from the population regarding the rank of the participants $\left(\chi^{2}(5)=11.93, p=0.036\right)$. Postdocs were slightly overrepresented in the sample (46.8\%) compared to the population (43.2\%) (VLIR, 2010).

\subsection{Variables}

The number of hours worked and the number of hours spent on specific tasks were collected by self-report. The respondents were asked how many hours they spent in an average week on research, education, service and administration. The total number of hours worked was calculated by adding the hours spent on these four tasks.

Bentley and Kyvik (2012) point to some potential problems with this manner of collecting time use data. First, 
there is a recall problem; participants may not be able to accurately recall how much time they spent on various activities. Several studies, however, show that this is not a major problem: when it occurs it is mainly at the extremes (Robinson \& Bostrom, 1994), and when comparing such results with recorded working hours no systematic bias is observed (Jacobs, 1998). Nevertheless, there is some problem with the accuracy of reporting as the data show clear evidence of heaping at multiples of 5 hours. A more serious problem may be that participants cannot always clearly distinguish between different types of activities. For instance, reading a scientific article may be relevant for one's research but also for one's teaching. Likewise, the supervision of doctoral students can be seen as either research and education tasks, or the participation in a program committee can be an education-related tasks as well as an administrative one. A final problem is the definition of an average week, one's time use may differ substantially in teaching and non-teaching weeks or during vacation period. In the SSR the participants were instructed to take into account both teaching and non-teaching periods. The survey was taken in June, i.e., just at the end of the spring semester, during the examination period when no classes were in session and education-related activities consisted mainly of the evaluation of students.

The Flemish system distinguishes four faculty ranks: lecturer (or assistant professor, 12.8\%), senior lecturer (associate professor, 12.8\%), full professor (8.6\%) and senior full professor (11.9\%). Besides these four categories we distinguish two more categories of senior researchers: postdocs (46.8\%) and 'other' (guest professors, etc., 5.3\%). The postdocs are the entry level position in the Flemish academic system (Debacker \& Vandevelde, 2016). Only the lucky few can progress to a tenured (before 2009) or tenure track (from 2009 on) assistant professor position. Their position can best be compared to a non-tenure track assistant or adjunct professor at US institutions, albeit with a reduced teaching load. Five major scientific disciplines are distinguished: life sciences, natural sciences, applied sciences, humanities and social sciences. Both the natural and life sciences account for somewhat less than $30 \%$ of the respondents, while the other three account each for about $15 \%$ of the respondents.

The sample contains $69.6 \%$ men and $30.4 \%$ women. The majority of the women $(64.1 \%)$ are postdocs, compared to only $39.3 \%$ of men $\left(\chi^{2}=78.98, \mathrm{DF}=5, \mathrm{p}=0.000\right)$. The age of the respondents was operationalized using their year of birth. The average year of birth was 1969 (SD: 10.1 years), which made the average respondent about 41 years old. About a fifth of the respondents (20.5\%) was born before 1960 and $11.7 \%$ in 1980 or later. The average respondent was working 7.9 years (SD: 7.4 years) in the current position (postdoc or faculty). This seniority is strongly associated with the respondent's rank $\left(\mathrm{E}^{2}=.502, \mathrm{~F}=239.0\right.$, DF: $\left.5 \& 1187, \mathrm{p}=0.000\right)$, with senior professors having a mean seniority of 19.7 years (SD: 6.9 years), while lecturers on the average have only 4.1 years of seniority (SD: 3.2). Postdoc also have low seniority as the time people can spend in this rank is limited ( $\bar{X}: 4.3$, SD: 4.1). Almost all respondents have full time appointments (87.4\%); only $9.2 \%$ had an appointment of $50 \%$ or less.

The family situation of the respondents is operationalized by their marital status and the presence of live-in children. The majority of the respondents are married or cohabitating with children $(61.2 \%)$ while another $20.5 \%$ is married or cohabitating without children. The singles without children make up $14.9 \%$ of the sample while $3.4 \%$ reported to be single with children in the household.

\section{Results}

\subsection{Total Number of Hours Worked}

As shown in Table 1 and Figure 1 senior researchers at Flemish universities report to work on the average 50.4 hours a week, which is considerably above the legal work week of 38 hours. The median is slightly lower at 49 hours a week. Only 30 respondents (or 2.3\%) reported to work fewer than 30 hours in an average week. At the other extreme $12.1 \%$ of the respondents (144/1195) report to work more than 60 hours a week with some outliers as high as 110 hours

Table 1. Descriptive statistics for number of hours worked

\begin{tabular}{ccccccc}
\hline & Mean & Median & SD & Minimum & Maximum & Mean proportion of time \\
\hline Total & 50.4 & 49.0 & 14.3 & 5 & 110 & $100.0 \%$ \\
Research & 25.8 & 25.0 & 12.8 & 0 & 60 & $53.0 \%$ \\
Education & 9.4 & 8.0 & 8.8 & 0 & 60 & $18.0 \%$ \\
Service & 7.0 & 5.0 & 8.3 & 0 & 60 & $13.1 \%$ \\
Administration & 8.2 & 5.0 & 7.4 & 0 & 50 & $15.9 \%$ \\
\cline { 2 - 7 } Note: $\mathrm{N}=1195$ & & & & & &
\end{tabular}

Note: $\mathrm{N}=1195$ 


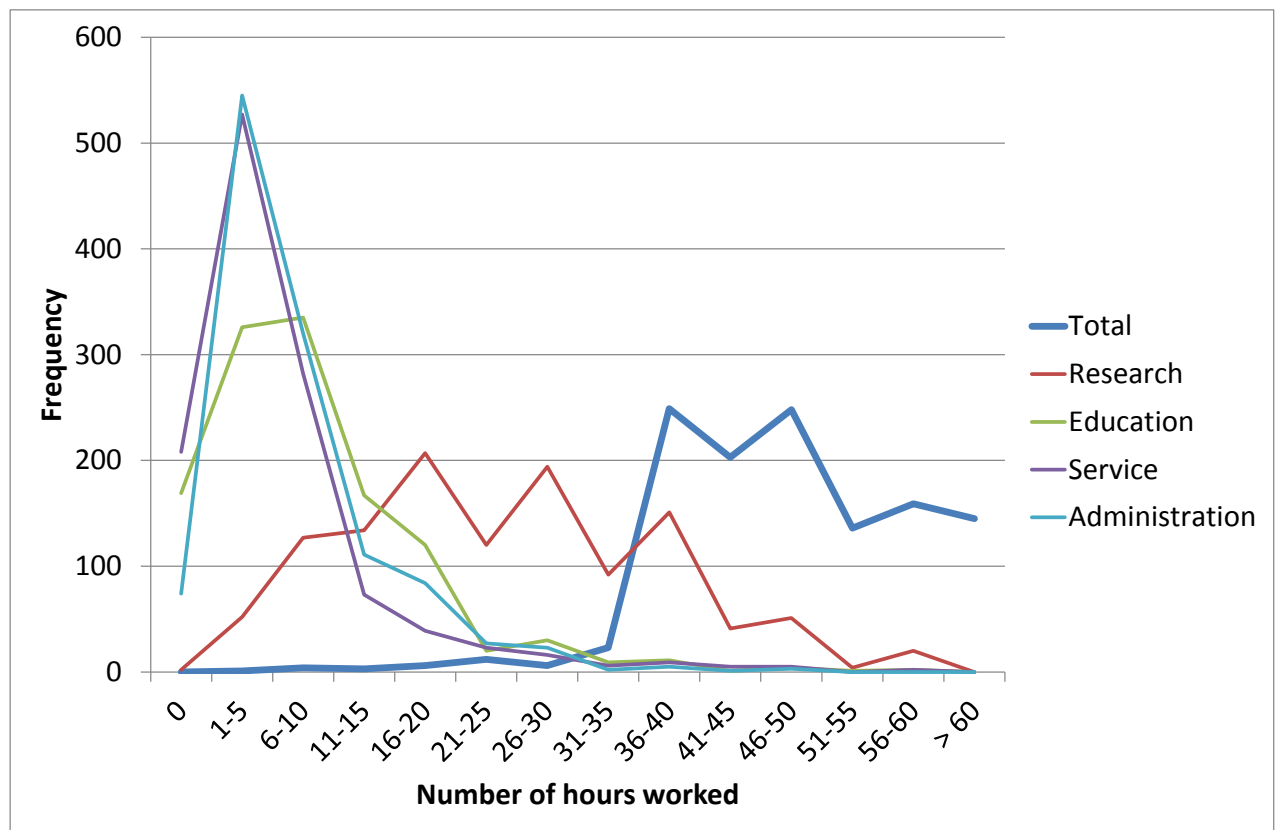

Figure 1. Frequency distributions of number of hours worked: total, research, education, service, and administration

Most of their time these senior researchers spend on research activities: on the average 25.8 hours a week or 53\% of their working time. There is however substantial variation, $15.1 \%$ of the respondents claim to spend 10 hours or less on research in an average week, while $19.7 \%$ reports 40 hours or more. Considerably less time is spent on the three other activities. For instance, on the average a senior researcher only spends 9.4 hours a week (18.0\%) on education related activities. Although more than half of the respondents report to spend between 5 and 15 hours a week on education activities, $14.1 \%$ say to spend no time at all on education, and $13.9 \%$ to spend 20 or more hours a week on it. The respondents on the average spend 8.2 hours a week (15.9\%) on administrative tasks and 7.0 hours on service related activities (13.1\%). Again some don't spend any time on administration $(6.2 \%)$ or service activities $(17.4 \%)$, but a considerable number spends 20 hours or more on administrative tasks $(11.5 \%)$ or service activities $(8.1 \%)$.

\subsection{Factors Affecting Total Number of Hours Worked}

As shown in Table 2 the total number of hours worked correlates positively with the percentage of the appointment. However, the relationship is weaker than might have been expected as most respondents hold full-time appointments. Furthermore, more senior or older respondents on the average also work more hours than more junior or younger researchers.

Table 2. Correlation between hours worked (total and by task) and percentage of appointment, seniority and year of birth

\begin{tabular}{lcrcrc}
\hline & $(1)$ Total & (2)Research & (3)Education & (4)Service & (5)Administration \\
\hline Percentage appointment & $0.067^{* * *}$ & $0.151^{* * *}$ & 0.011 & $-0.153^{* * *}$ & 0.024 \\
Seniority & $0.137^{* * *}$ & $-0.263^{* * *}$ & $0.189^{* * *}$ & $0.175^{* * *}$ & $0.299^{* * *}$ \\
Year of birth & $-0.204^{* * *}$ & $0.359^{* * *}$ & $-0.299^{* * *}$ & $-0.285^{* * *}$ & $-0.343^{* * *}$ \\
\hline
\end{tabular}

Note: significance: *: 0.050; **: 0.010;**: 0.001

The most important determinant of the total number of hours one works is one's rank (see Table 3). While postdocs on the average 'only' work 46.8 hours a week, lecturers on the average report 51.2 hours, senior lecturers and professors 54.4 hours, and senior professors even 57.7 hours. Postdocs work significantly fewer hours than each of the faculty ranks, and lecturers significantly less than senior professors. There is a clear trend towards longer work weeks when rising through the ranks. This is consistent with the findings regarding seniority and age, but goes in against the assumption that more senior faculty would experience fewer pressures to work longer hours. No significant differences were found in the average number of hours worked by scientific discipline. 
Table 3. Differences in number of hours worked (total and by task) by rank, discipline, gender and familial situation

\begin{tabular}{|c|c|c|c|c|c|c|}
\hline Variable & Statistic & (1) Total & (2) Research & (3) Education & (4) Service & (5) Administration \\
\hline \multirow[t]{2}{*}{ Total } & $\bar{x}$ & 50.4 & 25.8 & 9.4 & 7.0 & 8.2 \\
\hline & $s$ & 14.3 & 12.8 & 8.8 & 8.3 & 7.4 \\
\hline Rank & $\eta^{2}$ & $0.082 * * *$ & $0.171 * * *$ & $0.222 * * *$ & $0.088 * * *$ & $0.162 * * *$ \\
\hline \multirow[t]{2}{*}{ Senior professor } & $\bar{x}$ & 57.7 & 20.5 & 12.1 & 11.0 & 14.1 \\
\hline & $s$ & 17.3 & 11.8 & 8.4 & 10.3 & 9.6 \\
\hline \multirow[t]{2}{*}{ Professor } & $\bar{x}$ & 54.4 & 21.2 & 12.6 & 9.3 & 11.2 \\
\hline & $s$ & 13.0 & 11.0 & 6.7 & 7.7 & 7.2 \\
\hline \multirow[t]{2}{*}{ Senior lecturer } & $\bar{x}$ & 54.4 & 20.6 & 14.5 & 8.9 & 10.3 \\
\hline & $s$ & 14.4 & 10.7 & 9.7 & 9.1 & 6.9 \\
\hline \multirow[t]{2}{*}{ Lecturer } & $\bar{x}$ & 51.2 & 20.0 & 14.6 & 8.1 & 8.5 \\
\hline & $s$ & 13.4 & 11.1 & 9.5 & 7.4 & 5.4 \\
\hline \multirow[t]{2}{*}{ Postdoc } & $\bar{x}$ & 46.8 & 31.4 & 5.2 & 4.5 & 5.7 \\
\hline & s & 11.6 & 11.8 & 6.3 & 6.7 & 6.2 \\
\hline \multirow[t]{2}{*}{ Other } & $\bar{x}$ & 47.1 & 24.6 & 8.3 & 7.9 & 6.3 \\
\hline & $s$ & 20.4 & 15.6 & 9.3 & 9.8 & 6.5 \\
\hline Scientific discipline & $\eta^{2}$ & 0.007 & $0.012 * *$ & 0.066 *** & $0.040 * * *$ & $0.008^{*}$ \\
\hline \multirow[t]{2}{*}{ Life sciences } & $\bar{x}$ & 51.9 & 26.1 & 7.5 & 9.2 & 9.1 \\
\hline & $s$ & 16.0 & 13.1 & 7.8 & 11.5 & 7.3 \\
\hline \multirow[t]{2}{*}{ Natural sciences } & $\bar{x}$ & 49.2 & 27.4 & 8.8 & 5.1 & 7.8 \\
\hline & $s$ & 12.8 & 12.7 & 8.9 & 6.3 & 7.6 \\
\hline \multirow[t]{2}{*}{ Applied sciences } & $\bar{x}$ & 49.2 & 26.4 & 8.0 & 6.0 & 8.8 \\
\hline & $s$ & 13.1 & 13.2 & 6.7 & 6.1 & 9.1 \\
\hline \multirow[t]{2}{*}{ Humanities } & $\bar{x}$ & 51.3 & 23.4 & 14.4 & 6.2 & 7.3 \\
\hline & $s$ & 14.7 & 12.9 & 10.5 & 6.4 & 6.2 \\
\hline \multirow[t]{2}{*}{ Social sciences } & $\bar{x}$ & 50.7 & 24.2 & 10.6 & 8.1 & 7.8 \\
\hline & $s$ & 14.4 & 11.9 & 8.6 & 7.1 & 6.1 \\
\hline Gender & $\eta^{2}$ & $0.007 * *$ & $0.004 *$ & 0.002 & $0.006^{* *}$ & $0.017 * * *$ \\
\hline \multirow[t]{2}{*}{ Man } & $\bar{x}$ & 51.2 & 25.3 & 9.6 & 7.4 & 8.9 \\
\hline & $s$ & 14.1 & 12.9 & 8.5 & 8.3 & 7.8 \\
\hline \multirow[t]{2}{*}{ Woman } & $\bar{x}$ & 48.7 & 27.1 & 8.8 & 6.0 & 6.8 \\
\hline & $s$ & 14.6 & 12.6 & 9.5 & 8.2 & 6.2 \\
\hline Family situation & $\eta^{2}$ & 0.001 & $0.031 * * *$ & $0.013 * *$ & $0.009 *$ & $0.012 * *$ \\
\hline \multirow[t]{2}{*}{ Single, no children } & $\bar{x}$ & 49.3 & 28.3 & 7.9 & 5.5 & 7.5 \\
\hline & $s$ & 14.0 & 13.8 & 8.8 & 7.1 & 7.9 \\
\hline \multirow[t]{2}{*}{ Single, with children } & $\bar{x}$ & 50.3 & 19.6 & 12.4 & 7.1 & 11.1 \\
\hline & $s$ & 12.7 & 12.3 & 8.1 & 7.1 & 9.6 \\
\hline \multirow{4}{*}{$\begin{array}{l}\text { Married/cohabitating, } \\
\text { no children } \\
\text { Married/cohabitating, } \\
\text { with children }\end{array}$} & $\bar{x}$ & 50.7 & 28.9 & 8.3 & 6.3 & 7.2 \\
\hline & $s$ & 15.2 & 12.5 & 9.2 & 8.9 & 6.5 \\
\hline & $\bar{x}$ & 50.7 & 24.6 & 9.9 & 7.6 & 8.6 \\
\hline & $s$ & 14.1 & 12.4 & 8.6 & 8.4 & 7.4 \\
\hline
\end{tabular}

Note: significance: *: $0.050 ; * *: 0.010 ; * * *: 0.001$

Women on the average tend to work 2.5 hours a week less than their male colleagues, but this difference is explained away by the underrepresentation of women in the higher ranks and their overrepresentation among postdocs. When the effect of gender is controlled for rank, it becomes non-significant $(p=0.715)$. Family situation does not have a significant effect on the total number of hours worked either.

To summarize these results a regression tree analysis was run including all of the above variables. The advantage of such analysis is that it creates a 'decision' tree predicting different levels of working hours and allows for the detection of complex interactions among the variables. Only the variables retained by the analysis are shown in Figure 2. Again the most important factor affecting working time is the rank of the respondent, with the effects as described above. Among senior lecturers and professors the scientific discipline is of further importance those 
in the life sciences tend to work longer than their colleagues in the other disciplines, namely 58.8 (SD: 16.0) versus 52.9 hours (SD: 12.8), respectively. Among postdocs, gender is a further important factor as men on the average work 2.5 hours more than women, namely 47.9 hours (SD: 13.0) vs. 45.3 hours (SD: 12.2), respectively. Among male postdocs the extent of the appointment plays a further role, with full-time male postdocs (appointment $>90 \%$ ) working on the average about five hours longer each weak than their non-full-time colleagues (appointment $\leq 90 \%$ ).

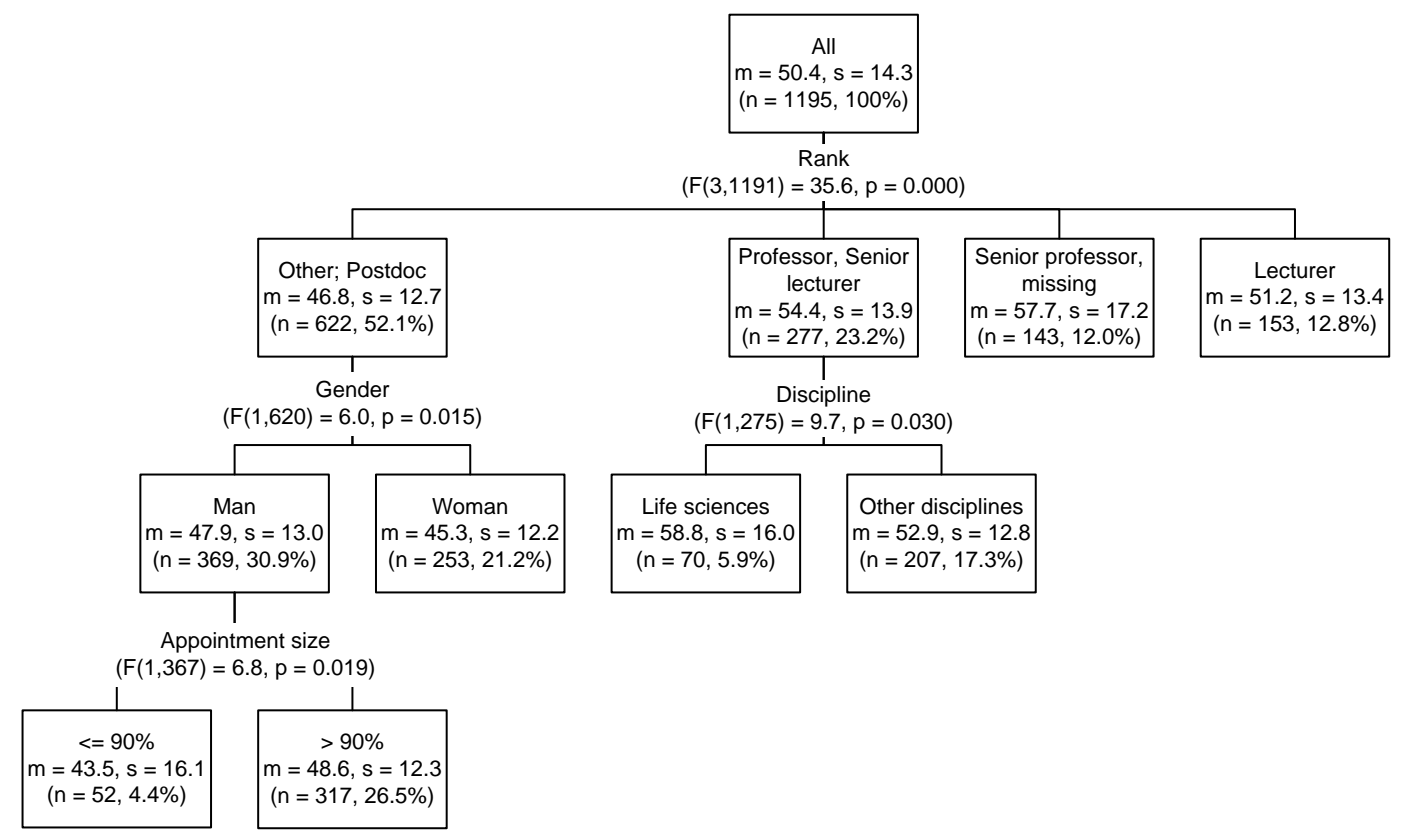

Figure 2. Tree diagram for total number of hours worked

\subsection{Trade-offs Between Time Spent on Various Tasks}

Table 4 illustrates the obvious trade-off between the time spent on research and on the three other activities. Respondents who spend more time on research tend to spend less time on education, administration and service activities. Remarkably, there is no trade-off among these latter three, when one spent more time on one of these activities, one also tended to spend more time on the other two. Controlling for the rank of the respondent weakens the correlations, but does not make them disappear completely. Only the partial correlation between times spent on education and service is non-significant.

Table 4. Zero-order and partial correlations among time spent on various activities

\begin{tabular}{|c|c|c|c|c|c|}
\hline & 1 & 2 & 3 & 4 & 5 \\
\hline 1 Research & & $-0.168 * * *$ & $-0.338 * * *$ & $-0.353 * * *$ & $0.388 * * *$ \\
\hline 2 Teac & $-0.326 * * *$ & & 0.024 & & $0.478 * * *$ \\
\hline 3 Service & -0.409 & $0.142 * * *$ & & $0.179 * * *$ & $0.392 * * *$ \\
\hline 4 Administrati & $-0.434 * * *$ & $0.214 * * *$ & $0.270 * * *$ & & $0.344 * * *$ \\
\hline 5 Total & $0.236 * * *$ & $0.516 * * *$ & $0.439 * * *$ & $0.416^{* * *}$ & \\
\hline
\end{tabular}

Note: Below diagonal: zero-order correlations; above diagonal: partial correlations controlling for respondent's rank.

significance: *: 0.050;**: 0.010; ***: 0.001

This trade-off between the different activities is further confirmed in Tables 2 and 3. For instance, more senior and older respondents spend less time on research and more on each of the three other activities. Rank also had a major effect on the time spent on the various activities. The main distinction here is between postdoc and faculty members. Postdocs, although they on the average have significantly shorter working weeks than the others, spend significantly more time on research, 31.4 hours a week on the average vs. 20.5 hours for faculty members. In return they spend significantly less time than all faculty ranks on the three other activities. No significant differences were observed among the faculty ranks with regard to the number of hours they spend on research 
and education. Senior professors spend significantly more time on service than lecturers, and more on administration than all other faculty ranks.

While the scientific discipline did not affect the total number of hours worked, it did affect the time spend on the various activities. For instance, scientific discipline explained almost $7 \%$ of the variance in time spent on education. This effect remains significant after controlling (Type I) for the effect of rank. Respondents from the humanities spend significantly more time on education than respondents from other disciplines, and those from the social sciences still significantly more than respondents from the life sciences or the applied sciences. The differences among the disciplines with regard to the other activities are less pronounced. In the natural sciences one spends significantly more time on research than in the humanities. This difference, however, becomes non-significant when controlling for rank. With regard to service activities it is mainly the respondents from the life sciences, and to a lesser degree those from the social sciences, who spend more time on service activities than respondents from the other disciplines. No significant pairwise differences among the disciplines were observed regarding the time spent on administrative tasks.

Significant differences by gender were observed for the time spent on research, service and administration. All these differences, however, became non-significant when controlling for the rank of the respondents. Likewise, the observed differences in time spent on education, service and administration by family situation all become non-significant after controlling for rank. Only with regard to the time spent on research does the effect of family situation remain: respondents without children spend more time on research than those with children, whether they are married or cohabitating or not.

\section{Discussion}

This study confirms that, like in other countries, senior researchers at Flemish universities work long hours. The average reported work week was over 50 hours, well above the standard workweek of 38 hours. The results show that faculty rank is by far the most important predictor of the length of one's work week, not only with regard to the number of hours one spends in total but also on research, education and administration. Only with regard to the time spent on service activities, rank was less and seniority more important. The total working time and the time spent on the other activities were also associated with the participant's seniority and age, but both of these factors, of course, strongly correlate with faculty rank.

Our findings further confirm a trade-off between the time spent on various activities. Spending more time on research implies spending less time on other activities. This suggests that the total time available for professional activities is relatively inelastic. The already high workload for many senior researchers renders it difficult for them to further extend their workweek.

The results provide little to no support for the competition hypothesis that predicts that senior researchers who are most engaged in a competition for scarce rewards, be it tenure or promotion, will tend to work the longest hours. To the contrary, it was exactly the group that faced most competition for future jobs, i.e., the postdoctoral researchers, who, on the average, had the shortest workweek. In fact, we observed the opposite of what one would expect based on the competition hypothesis: the average workweek increased with rank rather than declined. Of course, postdocs did spend significantly more time on research than researchers in other ranks as they have fewer education and administrative obligations.

One's time allocation is a function of the demands one experiences, demands that are both normative, organizational and practical in nature, and stem from various sources: the (inter)national scientific community, national and regional regulation, institutional organization and policies, and one's private life. It is up to the individual researcher to balance these various demands and to find a satisfactory solution. The variation in the demands experienced by the senior researcher depend both on his own characteristics (position in career, family situation, etc.) and on the institutional context. The most important contexts for senior researchers are their scientific discipline, the national or regional organization of the academic system, and the university. In the Flemish context the latter may be the least important, as no distinction is made between research and teaching universities. Non-university higher education institutions ("hogescholen") were not included in this study. As all universities are subjected to the same regulation and financing, few differences in overall demands on their research staff are observed. Much of the demands faced by the senior researchers therefore originate at the regional level that determines the evaluation and funding criteria for the institutions. As funding rules differ according to discipline -being more generous for the natural and life sciences - they also partially explain differences in experienced time pressures over the disciplines.

The data used in this study already data back to 2010. Since then the demands on senior researchers at Flemish universities have increased only further. This is part of world-wide trend for increased output and monitoring of 
university staff. Given the already long work week of the average senior researcher further extending one's working week may not be a realistic response. There are also limits to any increases in the pace of one's work. Any further productivity increases are likely to go at the expense of loss of quality of work (less thorough analyses in research, less time spent on course preparations, etc.) and increased stress.

The relationship between stress and well-being at work has received ample attention in the literature (e.g., Karasek et al., 1998; Karasek \& Theorell, 1990; Karasek, 1979). Both the stress one experiences and one's ability to cope with it to a considerable degree depend on the work organization and the characteristics of the job. Senior research and faculty positions are quite demanding jobs, potentially generating considerable stress. One factor helping people to cope with this stress is their job control. Faculty members traditionally had much autonomy regarding the content and organization of their work. This autonomy, however, is gradually eroded by an increasing regulation and monitoring of their work. That these evolutions negatively affect the job satisfaction of the faculty and researchers is demonstrated by recent protest actions, such as the petition against the increasing work pressures started by some academics in August 2013 and that attracted over 5000 signatures (Actiegroep Hoger Onderwijs, 2013) or statements of faculty in the press. The university administrations have acknowledged that there is a problem with the work load of faculty members. For instance, the president of the Free University of Brussels started his 2015 new year's speech with it (De Knop, 2015). In all universities the awareness of the problem is increasing, although no major changes have been implemented. And the Royal Flemish Academy of Belgium for the Sciences and the Arts (Bruynseraede et al., 2016) in a position paper makes recommendations to lower the demands on staff.

This study also has its limitations. The time use information is based on self-report and it was left to the participants to decide what they considered an average week and what constituted the various categories of activities. Although other studies have demonstrated that such approach does not necessarily lead to any bias in reporting, it cannot be excluded that some errors have crept in. If participants simply round upward the time spent on each of the activities one can get a systematic overestimation of the times spent. Given that the findings for the length of an average workweek in this study is consistent with the range observed in other international studies a substantial systematic bias is unlikely, but canno0t be excluded. A more objective measurement of the time use of senior researchers may be desired, but may be difficult to achieve.

Furthermore, the data used is cross-sectional. No comparable data on the time use of senior researchers at Flemish universities at an earlier or later moment is available, which means that this study cannot say anything about shifts in working times among Flemish academics. Although many senior researchers belief that work pressures have increased and that they work longer hours this study cannot confirm this as due to the lack of historical data. However, the main changes in the working times of senior researchers may have occurred over the past decade or so and for many senior researchers the number of hours worked per week may have peaked. However, a more recent survey on faculty (excluding postdocs) at a single Flemish university found similar results regarding the number of hours worked per week (Verbeylen, Minnen, van Tienoven, \& Glorieux, 2016).

Until recently Flemish universities did lack HR policies for their senior academic staff. The increased demands on these staff members and the decline in their autonomy, however, necessitates such policies. Recently universities have become aware that senior researchers, postdocs and faculty members alike, can no longer be left to their own device, and that they need specialized HR policies geared to this staff category. Given the many signs of deteriorating well-being and job satisfaction among the senior academic staff as the result of increasing job demands and deteriorating job control, a frequent monitoring of work pressures and well-being is warranted as well as measures to reduce such pressures and keep working hours within limits. Both financing and evaluation criteria should be reconsidered in this light.

\section{Acknowledgments}

We would like to thank the Ghemt University ECOOM team for the data collection and Dr. Katia Levecque for her feedback on earlier drafts of this manuscript.

\section{References}

Actiegroep Hoger Onderwijs. (2013). Actie hervorming hoger onderwijs. Retrieved from http://www.ipetitions.com/petition/actie-hervorming-hoger-onderwijs/

Anderson, D. M., \& Slade, C. P. (2016). Managing institutional research advancement: Implications from a university faculty time allocation study. Research in Higher Education, 57(1), 99-121. https://doi.org/10.1007/s11162-015-9376-9

Bbd [Dobbelaere, B]. (2010, 8 December). 'Iedereen moet harder werken, ook proffen'. De Standaard, p. 9. 
Benschop, Y., \& Brouns, M. (2003). Crumbling ivory towers: Academic organizing and its gender effects. Gender, Work \& Organization, 10(2), 194-212. doi:https://doi.org/10.1111/1468-0432.t01-1-00011

Bentley, P. J., \& Kyvik, S. (2012). Academic work from a comparative perspective: A survey of faculty working time across 13 countries. Higher Education, 63(4), 529-547. doi:https://doi.org/10.1007/s10734-011-9457-4

Blackburn, R. T., \& Lawrence, J. H. (1995). Faculty at work. Baltimore, MD: Johns Hopkins university press.

Bozeman, B., \& Gaughan, M. (2011). Job satisfaction among university faculty: Individual, work, and institutional determinants. The Journal of Higher Education, 82(2), 154-186. https://doi.org/10.1080/00221546.2011.11779090

Bruynhooghe, R. (2010). Proffentekort "We leefden boven onze stand". Veto, 37, 2.

Bruynseraede, Y., Dijn, H. D., Dyck, D. V., Veretennicoff, I., Willaert, F., Willems, D., \& Willems, J. (2016). Het professoraat anno 2016. Brussel: KVAB.

Craig, R., Amernic, J., \& Tourish, D. (2014). Perverse audit culture and accountability of the modern public university. Financial Accountability \& Management, 30(1), 1-24. https://doi.org/10.1111/faam.12025

Crane, D. (1969). Social structure in a group of scientists: A test of the "invisible college" hypothesis. American Sociological Review, 34(3), 335-352. https://doi.org/10.2307/2092499

Cummings, W. K., \& Finkelstein , M. J. (2012). Scholars in the changing American academy. New contexts, new rules and new roles. New York: Springer.

De Knop, P. (2015). De XII werken van de VUB. Nieuwjaarstoespraak van de rector. speech. Vrije Universiteit Brussel. Brussel.

Debacker, N., \& Vandevelde, K. (2016). From PhD to professor in Flanders. Gent: ECOOM, Universiteit Gent.

Dorenkamp, I., \& Süß, S. (2017). Work-life conflict among young academics: Antecedents and gender effects. European Journal of Higher Education, 7(4), 402-423. https://doi.org/10.1080/21568235.2017.1304824

Enders, J., \& Teichler, U. (1997). A victim of their own success?. Higher Education, 34, 347-372. https://doi.org/10.1023/A:1003023923056

Gappa, J. M. (2010). Rethinking faculty work and workplaces. In G. Gordon \& C. Whitchurch (Eds.), Academic and professional identities in higher education: The challenges of a diversifying workforce (pp. 207-222). New York, NY: Routledge.

Gardner, S. K., \& Veliz, D. (2014). Evincing the ratchet: A thematic analysis of the promotion and tenure guidelines at a striving university. The Review of Higher Education, 38(1), 105-132. https://doi.org/10.1353/rhe.2014.0045

Hackett, E. J., Parker, J. N., Vermeulen, N., \& Penders, B. (2017). The social and epistemic organization of scientific work. In U. Felt, R. Fouché, C. A. Miller, \& L. Smith-Doerr (Eds.), The handbook of science and technology studies (733-764). Cambridge, MA: MIT Press.

Jacobs, J. A. (1998). Measuring time at work: are self-reports accurate. Monthly Labor Review, 121(12), 42-53.

Jacobs, J. A., \& Winslow, S. E. (2004). The academic life course, time pressures and gender inequality. Community, Work \& Family, 7(2), 143-161. https://doi.org/10.1080/1366880042000245443

Karasek, R., Brisson, C., Kawakami, N., Houtman, I., Bongers, P., \& Amick, B. (1998). The Job Content Questionnaire (JCQ): an instrument for internationally comparative assessments of psychosocial job characteristics. Journal of Occupational Health Psychology, 3(4), 322-355.

Karasek, R., \& Theorell, T. (1990). Healthy work: stress, productivity and the reconstruction of working life. New York, NY: Basic books.

Karasek, R. A. (1979). Job demands, job decision latitude, and mental strain: Implications for job redesign. Administrative science quarterly, 24, 285-308. https://doi.org/10.2307/2392498

Kenny, J., \& Fluck, A. E. (2017). Towards a methodology to determine standard time allocations for academic work. Journal of Higher Education Policy and Management, 39(5), 503-523.

Kim, T. (2008). Changing university governance and management in the UK and elsewhere under market conditions: Issues of quality assurance and accountability. Intellectual Economics, 2(4), 35-42.

Knight, J. (2015). Five myths about internationalization. International higher education, 62. https://doi.org/10.6017/ihe.2011.62.8532 
Kurtz-Costes, B., Andrews Helmke, L., \& Ülkü - Steiner, B. (2006). Gender and doctoral studies. Gender and Education, 18(2), 137-155. https://doi.org/10.1080/09540250500380513

Leyman, A., Vandevelde, K., Van Rossem, R., \& Groenvynck, H. (2011). Senior onderzoekers aan het woord : resultaten van de 'survey of senior researchers' aan de Vlaamse universiteiten. Gent: Human Resources in Research $\left(\mathrm{HR}_{2}\right)$.

Link, A. N., Swann, C. A., \& Bozeman, B. (2008). A time allocation study of university faculty. Economics of Education Review, 27(4), 363-374. https://doi.org/10.1016/j.econedurev.2007.04.002

March, J. G., \& Olsen, J. P. (2006). Elaborating the "new institutionalism". In R. A. W. Rhodes, S. A. Binder, \& B. A. Rockman (Eds.), The Oxford handbook of political institutions (pp. 3-22). Oxford: Oxford University Press.

Massy, W. F., \& Zemsky, R. (1994). Faculty discretionary time: Departments and the "academic ratchet". The Journal of Higher Education, 65(1), 1-22. https://doi.org/10.1080/00221546.1994.11778471

Milem, J. F., Berger, J. B., \& Dey, E. L. (2000). Faculty time allocation: A study of change over twenty years. The Journal of Higher Education, 71(4), 454-475. https://doi.org/10.1080/00221546.2000.11778845

Ministerie van Onderwijs en Vorming. (2011). Hoger onderwijs in cijfers. Aantal inschijvingen op 31 oktober 2011. Academiejaar 2011-2012. Brussel: Ministerie van Onderwijs en Vorming.

Ministerie van Onderwijs en Vorming. (2017). Hoger onderwijs in cijfers. Academiejaar 2017-2018. Brussel: Ministerie van Onderwijs en Vorming.

Reay, D. (2004). Cultural capitalists and academic habitus. Women's Studies International Forum, 27(1), 31-39. https://doi.org/10.1016/j.wsif.2003.12.006

Robinson, J. P., \& Bostrom, A. (1994). The overestimated workweek-what time diary measures suggest. Monthly Labor Review, 117(8), 11-23.

Scott, W. R. (2008). Institutions and organizations. (3rd ed.). Los Angeles, CA: Sage.

Seeber, M., Cattaneo, M., Huisman, J., \& Paleari, S. (2016). Why do higher education institutions internationalize? Higher education, 72(5), 685-702. https://doi.org/10.1007/s10734-015-9971-x

Singell, L. D., \& Lillydahl, J. H. (1996). Will changing times change the allocation of faculty time? Journal of Human Resources, 31(2), 429-449. https://doi.org/10.2307/146070

Teichler, U. (2017). Teaching versus research: An endangered balance? In M. d. L. Machado-Taylor, V. M. Soares, \& U. Teichler (Eds.), Challenges and options (pp. 11-28). Cham: Springer.

Teixeira, P. N. (2017). A bastion of elitism or an emerging knowledge proletariat?. In M. d. L. Machado-Taylor, V. M. Soares, \& U. Teichler (Eds.), Challenges and options (pp. 29-47). Cham: Springer.

Trakman, L. (2008). Modelling university governance. Higher Education Quarterly, 62(1-2), 63-83. doi:https://doi.org/10.1111/j.1468-2273.2008.00384.x

Van den Brink, M. (2010). Behind the scenes of science. Amsterdam: Amsterdam University Press.

Verbeylen, J., Minnen, J., van Tienoven, T. P., \& Glorieux, I. (2016). Taakbelasting en taakinvulling van het ZAP aan de Vrije Universiteit Brussel. Brussel: Vrije Universiteit Brussel, TOR.

Vlaamse Raad voor Wetenschapsbeleid. (2008a). Beleidsbrief 2008 'Economie, ondernemen, wetenschap, innovatie en buitenlandse handel'. Brussel: Vlaamse Raad voor Wetenschapsbeleid.

Vlaamse Raad voor Wetenschapsbeleid. (2008b). Doctoraatsbeurzen en postdoctorale mandaten. Brussel: Vlaamse Raad voor Wetenschapsbeleid.

VLIR, Vlaamse Interuniversitaire Raad. (2010). Statistische gegevens betreffende het personeel aan de Vlaamse universiteiten. Telling 1 februari 2010. Brussel: VLIR.

VLIR, Vlaamse Interuniversitaire Raad. (2012). Statistische gegevens betreffende het personeel aan de Vlaamse universiteiten. Telling 1 februari 2012. Brussel: VLIR.

VLIR, Vlaamse Interuniversitaire Raad. (2017). Statistische gegevens betreffende het personeel aan de Vlaamse universiteiten. Telling 1 februari 2017. Brussel: VLIR.

Welch, A. R. (2005). The professoriate. Dordrecht: Springer.

Winslow, S. (2010). Gender inequality and time allocations among academic faculty. Gender \& Society, 24(6), 
769-793. https://doi.org/10.1177\%2F0891243210386728

Zemsky, R., Wegner, G. R., \& Massy, W. F. (2005). Remaking the American university: Rutgers University Press.

\section{Copyrights}

Copyright for this article is retained by the author(s), with first publication rights granted to the journal.

This is an open-access article distributed under the terms and conditions of the Creative Commons Attribution license (http://creativecommons.org/licenses/by/3.0/). 